\title{
Study Analysis of Voltage Drop in a Typical Office Building Lighting System: A Case Study of of FEM IPB Building Electrical Installation
}

\author{
$1^{\text {st }}$ Chico Hermanu Brillianto Apribowo \\ Electrical Engineering Department \\ Faculty of Engineering \\ Sebelas Maret University \\ Surakarta, Indonesia \\ chico@ft.uns.ac.id \\ $2^{\text {nd }}$ Ghea Faradiba \\ Electrical Engineering Department \\ Faculty of Engineering \\ Sebelas Maret University \\ Surakarta, Indonesia \\ 12.gheafaradiba@gmail.com
}

\author{
$3^{\text {rd }}$ Feri Adriyanto \\ Electrical Engineering Department \\ Faculty of Engineering \\ Sebelas Maret University \\ Surakarta, Indonesia \\ feri.adriyanto@staff.uns.ac.id \\ $4^{\text {th }}$ Oktavian Listiyanto \\ Electrical Engineering Department \\ Faculty of Engineering \\ Sebelas Maret University \\ Surakarta, Indonesia \\ 29.oktavian@gmail.com
}

\begin{abstract}
Design of electrical system in the Faculty of Economics and Management Bogor Agricultural Institute was based guidance consisting of PUIL, SNI, as well as provisions of modern security and technology and aesthetic beauty. Design is also based on the relevant IEC standards, specifically IEC 60364. In the electrical system, it is necessary to pay attention to the conductor and safety factor to minimize power losses and drop voltage. Losses on the customer side due to drop voltage besides damaging electrical equipment is customers only can have a voltage less than $220 \mathrm{~V}$. The distance between load panel and main panel is directly proportional to the drop voltage value, much farther the load panel to the main panel, resulting greater drop voltage value produced. The calculation of drop voltage based on total load, length, and area of conductor. To overcome the problems that occurred in this case study, the conductor uses 1.25 times the nominal current as a safety factor. The selection area of conductor can be said to be quite good with the farthest drop voltage value from SDP-TR is $0.89 \%$. The total amount of electricity in the building is $158.33 \mathrm{kVA}$, assuming that if there is an additional 5-10 years, the total electric power and $15 \%$ of the others SDP is $182.04 \mathrm{kVA}$.
\end{abstract}

Keywords-electrical work planning, PUIL, SNI, IEC

\section{INTRODUCTION}

A good electrical installation aims to ensure human safety from the danger of electric shock, the safety of electrical installations and their equipment, the safety of buildings and their contents from electric fire, and environmental protection [1]. Quality and safety will only be guaranteed if the design is carried out by the latest regulations, electrical equipment that complies with relevant product standards, initial checks on standards and regulations have been achieved and recommended periodic installation checks.

The energy efficiency of a building's electrical installation system is influenced by two aspects, namely power losses or losses on the cable and the efficiency of the equipment used [2]. Voltage drops will occur along the line that is passed during the transmission of electricity both transmission and distribution. Different parts of the voltage in a power system cause a voltage drop and are also influenced by several factors such as resistance, reactance, and impedance in the line. The voltage drop on the line is the difference between the voltage at the base of the shipment and the voltage at the receiving end of electricity [3]. The problem that often occurs in the field until now is the voltage drop that exceeds the established tolerance limit. To minimize the voltage drop on the line, it can be done by increasing the selection of the conductor cross-section size used.

\section{LITERATURE REVIEW}

\section{A. Calculation of Lighting Installation}

The stages of lighting installation calculation are as follows:

1. Determine data size from room planning.

2. Determine minimum lighting levels based on applicable standards (BSN, 2011).

3. Determine the planned lighting level ( $\mathrm{F}$ total),

Where:

$$
F \text { total }=\frac{E \times A}{K p \times K d} \text { (lumen) }
$$

$\mathrm{E} \quad=$ Minimum lighting level (lux)

A $\quad=$ Area of work $\left(\mathrm{m}^{2}\right)$

$\mathrm{Kp} \quad=$ Usage coefficient

$\mathrm{Kd}=$ Depreciation coefficient.

4. Determine the type of lamp that will be used.

5. Determine the number of lamp armatures ( $\mathrm{N}$ total),

Where:

$$
N \text { total }=\frac{F \text { total }}{F 1 \times n}
$$

$\mathrm{F}$ total = planned lighting level (lumens)

F1 = One lamp flux (lux)

$\mathrm{n}=$ Number of lights in one armature (pieces) 


\section{B. Current Conduct Ability}

The cross-sectional area of conductors in an electrical installation is determined based on the current passing through the conductor using the equation:

a. single phase alternating current

$$
I=\frac{p}{V x \operatorname{Cos} \varphi} A
$$

b. three-phase alternating current

$$
\begin{array}{ll}
\mathrm{I} & =\text { Nominal current }(\mathrm{A}) \\
\mathrm{P} & =\text { Active power }(\mathrm{W}) \\
\mathrm{V} & =\text { Voltage }(\mathrm{V}) \\
\operatorname{Cos} \varphi & =\text { Power factor }
\end{array}
$$$$
\text { Where: }
$$$$
I=\frac{P}{\sqrt{3} x V x \operatorname{Cos} \varphi} A
$$

The conductivity of the current used in the selection of conductors is 1.25 times the amount of current that passes through the conductor based on PUIL 2000. After knowing the conductivity of the current, the next step is to adjust the catalog to find the appropriate conductor cross-sectional area.

\section{Protection}

$\mathrm{MCB}$ and MCCB function as safety short-circuit current and overload. The capacities of MCB and MCCB are chosen by knowing the ability to conduct a circuit breaker current which is 1.45 times the nominal current based on PUIL 2011. Nominal current is known by Equations (3) and (4).

\section{Voltage drop}

Voltage drop is the amount of loss caused by resistance and reactance in a conductor. Calculation of voltage drop $(\Delta \mathrm{U})$ and the percentage loss refers to the electrical installation guide book published by Schneider Electric with the equation:

$$
\begin{gathered}
\Delta \mathrm{U}=\sqrt{3} \times \operatorname{In} \times[(\mathrm{R} \operatorname{Cos} \varphi)+(\mathrm{X} \operatorname{Sin} \varphi)] \times \mathrm{L} \\
\text { in } \%=\frac{100 \times \Delta \mathrm{U}}{\mathrm{Un}}
\end{gathered}
$$

Where:

$$
\begin{aligned}
& \Delta \mathrm{U}=\text { Conducting voltage } \operatorname{drop}(\mathrm{V}) \\
& \mathrm{I}=\text { Strong conductance current }(\mathrm{A})
\end{aligned}
$$

$(\mathrm{R} \operatorname{Cos} \varphi+\mathrm{X} \operatorname{Sin} \varphi)=$ Resistance and conductance of conductor $(\Omega / \mathrm{km})$

$$
\begin{aligned}
& \mathrm{L}=\text { length of conductor }(\mathrm{km}) \\
& \mathrm{Un}=\text { Phase to phase voltage }(\mathrm{V})
\end{aligned}
$$

\section{METHOD}

The Faculty of Economics and Management building is located at the Bogor Institute of Agriculture with a view of the building that can be seen in Figure 1 which consists of 4 floors with the total area of the building located on a land area of around 1.22 hectares.
The required data such as building layout drawings, the overall area of the building, the floor plan, the function of the room and the system of each floor to obtain the capacity of the transformer and generator set. The distribution system in planning allows the load point to be served from two directions of electric power sources, namely the supply of PLN and generator sets, so that continuity of service is guaranteed, and the power quality is better because the voltage losses and power losses on the channel become smaller.

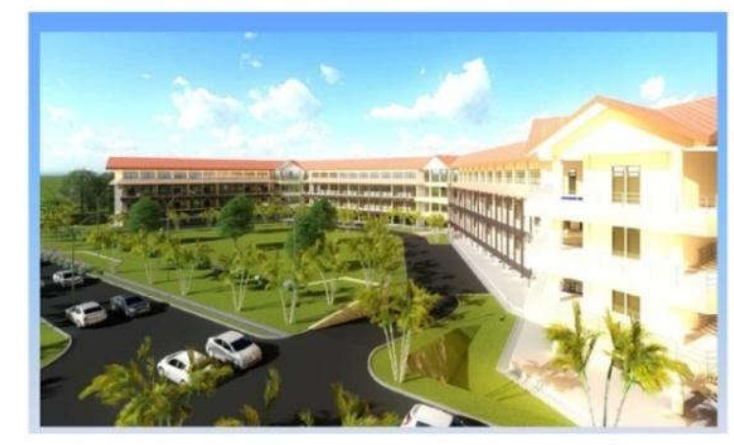

(4)

Figure 1. Faculty of Economics and Management Building

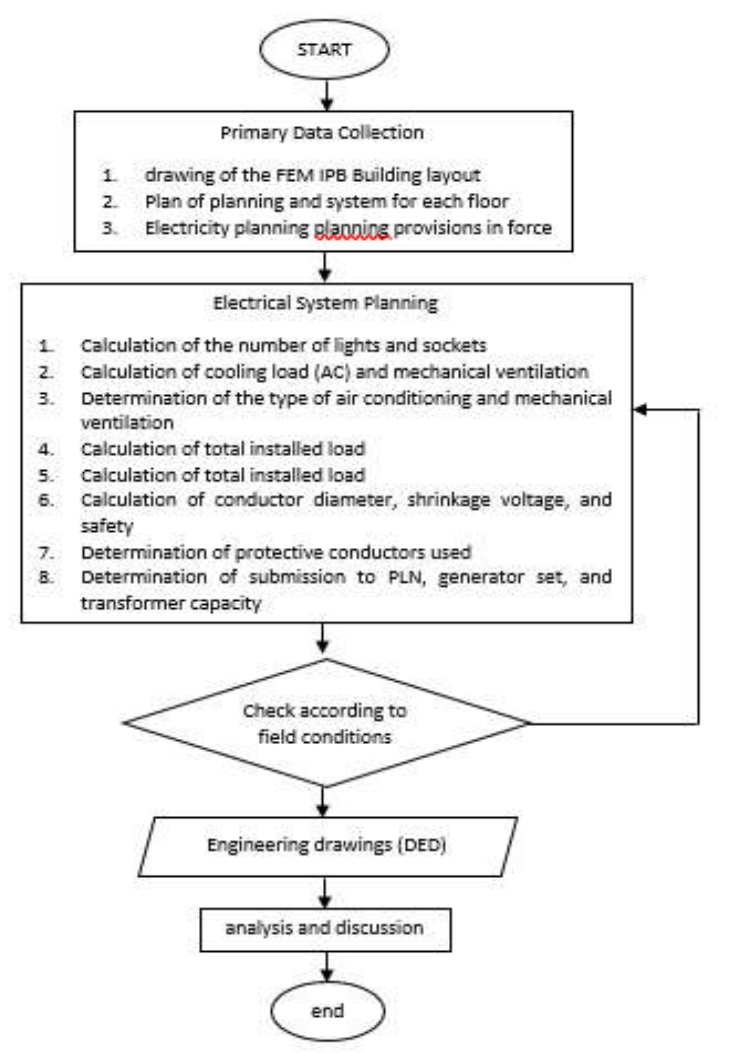

Figure 2. Building planning flow chart

Tabel 1. Function and area of each floor

\begin{tabular}{|c|l|c|}
\hline Floor & \multicolumn{1}{|c|}{ Room } & Area $\left(\mathrm{m}^{2}\right)$ \\
\hline \multirow{4}{*}{1} & $\begin{array}{l}\text { Discussion } \\
\text { Room }\end{array}$ & 81,0 \\
\cline { 2 - 3 } & lecture hall & 121,5 \\
\cline { 2 - 3 } & lecturer waiting & 40,5 \\
\hline
\end{tabular}




\begin{tabular}{|c|c|c|}
\hline Floor & Room & Area $\left(\mathrm{m}^{2}\right)$ \\
\hline & room & \\
\hline & court room & 162,0 \\
\hline & Toilet 1 & 5,0 \\
\hline & Toilet 2 & 4,1 \\
\hline & Toilet 3 & 5,0 \\
\hline & Toilet 4 & 4,1 \\
\hline & kitchen & 6,0 \\
\hline & Panel room & 6,0 \\
\hline & women's toilet & 23,2 \\
\hline & men's toilet & 23,3 \\
\hline & $\begin{array}{l}\text { student } \\
\text { secretariat }\end{array}$ & 46,8 \\
\hline & the hallway 1 & 305,9 \\
\hline & the hallway2 & 283,8 \\
\hline \multirow{21}{*}{2} & $\begin{array}{l}\text { examination } \\
\text { room1 }\end{array}$ & 40,5 \\
\hline & $\begin{array}{l}\text { examination } \\
\text { room2 }\end{array}$ & 40,5 \\
\hline & Seminar room & 121,6 \\
\hline & staff room & 80,9 \\
\hline & treasurer room & 28,5 \\
\hline & $\begin{array}{l}\text { the department } \\
\text { secretary's } \\
\text { room }\end{array}$ & 17,9 \\
\hline & $\begin{array}{l}\text { living room } \\
\text { department }\end{array}$ & 35,9 \\
\hline & $\begin{array}{l}\text { the department } \\
\text { chair's room }\end{array}$ & 22,6 \\
\hline & Janitor & 2,1 \\
\hline & Toilet 1 & 5,0 \\
\hline & Toilet 2 & 4,1 \\
\hline & Toilet 3 & 4,37 \\
\hline & Toilet 4 & 5,0 \\
\hline & Toilet 5 & 4,1 \\
\hline & Kitchen & 6,0 \\
\hline & Panel Room & 6,0 \\
\hline & women's toilet & 23,2 \\
\hline & men's toilet & 23,3 \\
\hline & $\begin{array}{l}\text { student } \\
\text { secretariat }\end{array}$ & 46,8 \\
\hline & the hallway 1 & 305,9 \\
\hline & the hallway2 & 283,8 \\
\hline \multirow[t]{15}{*}{3} & lecture hall 1 & 121,5 \\
\hline & lecture hall 2 & 121,5 \\
\hline & lecturer room 1 & 20,2 \\
\hline & lecturer room 2 & 20,2 \\
\hline & lecturer room 3 & 20,3 \\
\hline & lecturer room 4 & 20,1 \\
\hline & lecturer room 5 & 20,1 \\
\hline & student room & 40,5 \\
\hline & $\begin{array}{l}\text { Islamic Prayer } \\
\text { Room }\end{array}$ & 20,3 \\
\hline & ablution room & 2,3 \\
\hline & Toilet 1 & 5,0 \\
\hline & Toilet 2 & 4,1 \\
\hline & Toilet 3 & 2,7 \\
\hline & Toilet 4 & 4,1 \\
\hline & Panel room & 6,0 \\
\hline
\end{tabular}

\begin{tabular}{|c|c|c|}
\hline Floor & Room & Area $\left(\mathrm{m}^{2}\right)$ \\
\hline & women's toilet & 23,2 \\
\hline & men's toilet & 23,3 \\
\hline & $\begin{array}{l}\text { student } \\
\text { secretariat }\end{array}$ & 46,8 \\
\hline & the hallway 1 & 305,9 \\
\hline & the hallway2 & 283,8 \\
\hline \multirow[t]{14}{*}{4} & $\begin{array}{l}\text { lecturer room } \\
1-17\end{array}$ & 16,2 \\
\hline & $\begin{array}{l}\text { Islamic Prayer } \\
\text { Room }\end{array}$ & 16,2 \\
\hline & ablution room & 3,4 \\
\hline & Toilet 1 & 3,4 \\
\hline & Toilet 2 & 3,4 \\
\hline & Toilet 3 & 3,4 \\
\hline & R. Dapur & 6,9 \\
\hline & R. Panel & 6,9 \\
\hline & Koridor & 72,8 \\
\hline & R. Umum & 40,4 \\
\hline & women's toilet & 23,2 \\
\hline & men's toilet & 23,3 \\
\hline & $\begin{array}{l}\text { student } \\
\text { secretariat }\end{array}$ & 46,8 \\
\hline & the hallway & 283,8 \\
\hline
\end{tabular}

\section{RESULT AND DISCUSSION}

\section{A. Lightning Installation}

Most types of rooms in the electrical design of buildings are square-shaped with different room functions. The number of light points needed for each room depends on the function and area of the room. Calculation of the number of armature and lights in the room is intended to get a good level of lighting. Reference for use of armature and lamps using Philips product catalog. The following is an example of the calculation of lighting in a room taken as an example of the 1 st-floor discussion room.

\section{Room data:}

$\begin{array}{ll}\text { Room length }(\mathrm{p}) & =9 \mathrm{~m} \\ \text { Room width }(\mathrm{l}) & =9 \mathrm{~m} \\ \text { Room height }(\mathrm{h}) & =4.5 \mathrm{~m} \\ \text { Kp (new building) } & =0.9 \\ \text { Kd (BSN, 2001) } & =0.8 \\ \text { E (classroom) } & =350 \text { lux }\end{array}$

With Equation (1) a total flux of

$$
\begin{aligned}
\mathrm{F} \text { total } & =\frac{350 \times(9 \times 9)}{0,9 \times 0,8} \\
& =39375 \text { lumen }
\end{aligned}
$$

The type of lamp used is the MASTER TL-D Secura Philips Lighting $36 \mathrm{~W}$ with F1 of 3200 lumens. With Equation (2), the number of armatures/lights is obtained,

$$
\begin{aligned}
\mathrm{N} \text { total } & =\frac{39375}{3200 \times 2} \\
& =6,15 \rightarrow 12 \text { lamp }
\end{aligned}
$$


The number of armatures in the discussion room on the 1 st floor is 6 pieces or 12 lamps $36 \mathrm{~W}$. The results of laying the number of lighting lamps are shown in Figure 3.

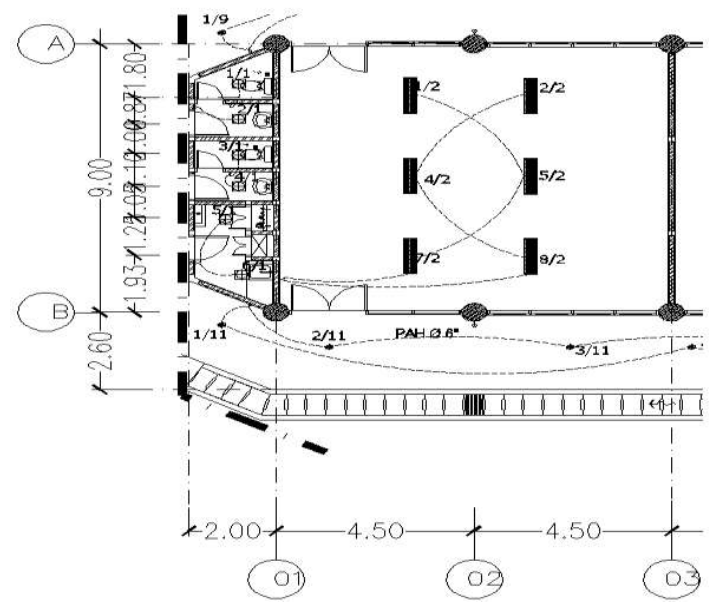

Figure 3. $1^{\text {st }}$ floor discussion room lighting installation

\section{B. Determination of Electric Power}

The results of the calculation of electric power per floor are shown in Table 2.

Tabel 2. Building electrical power

\begin{tabular}{|c|c|c|c|c|c|}
\hline \multirow{2}{*}{ Floor } & \multicolumn{4}{|c|}{ power equipment (VA) } & $\begin{array}{c}\text { Total } \\
\text { power } \\
\text { equipment } \\
\text { (VA) }\end{array}$ \\
\cline { 2 - 5 } & Lamp & AC & EF & $\begin{array}{c}\text { Socket } \\
\text { Outlet }\end{array}$ & 40471,25 \\
\hline 1 & 5335 & 29506,25 & 130 & 5500 & 41376,25 \\
\hline 2 & 5173.75 & 28806,25 & 146,25 & 7250 & 40122,5 \\
\hline 3 & 5695 & 28297,5 & 130 & 6000 & 34686,25 \\
\hline 4 & 3885 & 19171,25 & 130 & 11500 & 23498,43 \\
\hline $\begin{array}{c}\text { SDP } \\
\text { reserve }\end{array}$ & $\begin{array}{l}\text { Other backup equipment if needed to develop } \\
15 \% \text { of the total VA }\end{array}$ & 180154,68 \\
\hline \multicolumn{7}{|c|}{ Total VA + VA SDP reserve } \\
\hline
\end{tabular}

The total electric power of the Faculty of Economics and Management Building is $156.65 \mathrm{kVA}$. Assuming an additional $15 \%$ of the total power for the reserve SDP, the building's total electrical power is $180.15 \mathrm{kVA}$. Based on the calculation of total power, the selected step down transformer has a capacity of $200 \mathrm{kVA}$ (Trafindo, 2013) and a generator set with a capacity of $200 \mathrm{kVA}$ open type (Komatsu, 2017).

\section{Calculation of Conductional Cross-sectional Area}

As an example of the calculation of the conductor crosssectional area is the main conductor of SDP-TR to PP floor 1. Calculation methods applied include:

1. Determine the nominal current

Using Equation (4), the nominal current of the conductor is,Sebagai contoh untuk perhitungan luas penampang penghantar adalah penghantar utama SDP-TR ke PP lantai 1. Metode perhitungan yang diterapkan meliputi:

$$
\begin{aligned}
\text { In } & =6.655 /(\sqrt{ } 3 \times 380) \\
& =10,11 \mathrm{~A}
\end{aligned}
$$

2. Determine the type and capacity of the $\mathrm{MCB} / \mathrm{MCCB}$

Determination of the safety current rating can be determined by calculating the nominal current flowing in the circuit. Calculation of the safety current rating is based on PUIL 2011 pages $80-82$,

$$
\begin{array}{r}
\mathrm{I}_{\mathrm{MCB} / \mathrm{MCCB}}=1,45 \times 10,11 \mathrm{~A} \\
=14,66 \mathrm{~A}
\end{array}
$$

Calculation of circuit breakers refers to SNI IEC 60898 1: 2009 concerning overcurrent protection for installation Then the MCB used is the MCB iC60N 3P $20 \mathrm{~A}$, with a disconnection capacity of $10 \mathrm{kA}$.

3. Determine the conductor cross-section

Based on the safety current obtained by the KHA of,

$$
\begin{aligned}
\mathrm{KHA} & =1,25 \times 25 \mathrm{~A} \\
& =31 \mathrm{~A}
\end{aligned}
$$

From the calculation, the maximum current that can pass through the conductor is $31 \mathrm{~A}$, so that the appropriate cable for use is NYY 4x6 mm2 (Voksel Electric, 2011). With a maximum current capacity that can be received if the installation in the air is $44 \mathrm{~A}$, while the installation in the ground is $52 \mathrm{~A}$. Calculations using the same method are carried out for all building installations. Types of conductors used at the Faculty of Economics and Management Building are NYM, NYY, N2XSEFGbY, and N2XSY.

\section{Voltage Drop Calculation}

The calculation of the biggest voltage drop in the Faculty of Economics and Management Building is from the farthest distance from SDP-TR to PP 4th floor. By using Equation:

$$
\begin{gathered}
\mathrm{R} \operatorname{Cos} \varphi+\mathrm{X} \operatorname{Sin} \varphi=3,002 \Omega / \mathrm{km} \\
\mathrm{L}=38,5 \mathrm{~m}=0,0385 \mathrm{~km}
\end{gathered}
$$

By using Equations (5) and (6) a voltage drop of

$$
\begin{aligned}
\Delta \mathrm{U} & =\sqrt{3} \times 17,02 \times 3,002 \times 0,0385 \\
& =3,4 \mathrm{~V}
\end{aligned}
$$

So the percentage of voltage drops is,

$$
\text { In } \begin{aligned}
\% & =\frac{100 \times 3,4}{380} \\
& =0,89 \%
\end{aligned}
$$

The voltage drop value obtained does not exceed that required by IEC 60364-5-52 which is 3\% for low voltage lighting circuits. The results of the voltage drop calculation for each electrical panel are shown in Table 3.

\section{CONCLUSION}

From the results of electrical system calculations that have been carried out, it can be concluded that:

1. The total electrical power of the building is $180.15 \mathrm{kVA}$ with the selection of $200 \mathrm{kVA}$ step down transformer and $200 \mathrm{kVA}$ generator set with open type.

2. From the voltage drop calculation data it appears that the farther the distance of the load panel to the main panel, the greater the voltage drop value. For maximum voltage 
drop occurs in the panel farthest from the main panel that is $0.89 \%$ or $3.4 \mathrm{~V}$.

(4) the nominal current obtained from SDP-TR to PP 4th floor is equal to

$$
\begin{aligned}
\text { In } & =\frac{11.205}{\sqrt{3} \times 380} \\
& =17,02 \mathrm{~A}
\end{aligned}
$$

The assumption used is, $\cos \varphi=0,8$ kabel NYY 4x6 $\mathrm{mm}^{2}$

\section{REFERENCES}

[1] BSN, 2000, SNI-04-0225-2000: Persyaratan Umum Instalasi Listrik 2000 (PUIL 2000), Jakarta.

[2] L. Hadjidemetriou, L. Zacharia, dan E. Kyriakides, "Cost-Effective Optimization for an Energy Efficient Design of Electrical Installations of Buildings," IEEE KIOS Research and Innovation Center of Excellence and Department of Electrical and Computer Engineering, 2018.
[3] Abrar Tanjung, "Analisis Kinerja Sistem Kelistrikan Universitas Lancang Kuning”, Seminar Nasional Teknologi Informasi, Komunikasi dan Industri (SNTIKI) 7, November 2015.

[4] RB Budi Kartika W, "Perencanaan Instalasi Listrik 220 Volt Gedung Hanggar Sekolah Tinggi Penerbangan Indonesia," Jurnal Ilmiah Aviasi Langit Biru, vol. 10, no. 2, Juni 2017.

[5] Ulul Ilmi dan Sukardi, “Analisa Instalasi Listrik Pada Rusunuwa Dengan Metode Studi Deskriptif Kasus Rusunuwa Universitas Islam Lamongan,” Jurnal JE-Unisla, vol. 2, no. 1, Maret 2017.

[6] Ulil Albab Al Faruq, Budi Santoso, dan Chico Hermanu B. Apribowo, "Perencanaan Sistem Elektrikal pada Apartemen Menara One Surakarta", Jurnal Mekanika, vol. 17, no. 1, Maret 2018.

[7] Voksel Electric, Product Catalogue, Jakarta: PT Voksel Electric Tbk, 2011.

[8] Schneider Electric, Electrical Installation Guide, Jakarta: Schneider Electric Industries SAS, 2018.

[9] BSN, 2011, SNI-6197: Konservasi Energi pada Sistem Pencahayaan, Jakarta.

[10] Philips Lighting, Philips Lighting LED Professional Solutions, Belanda: Philips Lighting, 2017.

[11] Komatsu, Air to Air aftercooled Engine, Jepang: Komatsu Ltd. Generator \& Engine Overseas Marketing Department, 2016.

[12] Trafindo, Katalog Produk Trafo Distribusi SPLN D3, Jakarta: PT Trafoindo Prima Perkasa, 2013.

\begin{tabular}{|c|c|c|c|c|c|c|c|}
\hline \multirow[b]{2}{*}{ Location } & \multirow[b]{2}{*}{ load classification } & \multicolumn{4}{|c|}{ conductor } & \multicolumn{2}{|c|}{ Voltage drop } \\
\hline & & Conductor option & $\begin{array}{c}\text { Resistance } \\
(\Omega / \mathrm{km})\end{array}$ & $\begin{array}{c}\text { Inductance } \\
(\mathrm{mH} / \mathrm{km})\end{array}$ & $\begin{array}{c}\text { Inductive } \\
\text { Reactance }(\Omega)\end{array}$ & Length $(\mathrm{km})$ & $\Delta \mathrm{U}(\mathrm{V})$ \\
\hline \multirow{4}{*}{$1^{\text {st }}$ Floor } & LP/PP LT.1 & NYY 4 × $6 \mathrm{~mm}^{2}$ & 3,685 & 0,288 & 0,09043 & 0,025 & 1,31 \\
\hline & LP/PP NODE LT.1 & NYY 4 x $4 \mathrm{~mm}^{2}$ & 5,516 & 0,303 & 0,09514 & 0,025 & 1,22 \\
\hline & VAC LT.1 & NYY 4 × $25 \mathrm{~mm}^{2}$ & 0,87 & 0,255 & 0,08007 & 0,025 & 1,32 \\
\hline & VAC NODE LT.1 & NYY $4 \times 2,5 \mathrm{~mm}^{2}$ & 8,866 & 0,304 & 0,09546 & 0,025 & 1,17 \\
\hline \multirow{4}{*}{$2^{\text {nd }}$ Floor } & LP/PP LT.2 & NYY $4 \times 6 \mathrm{~mm}^{2}$ & 3,685 & 0,288 & 0,09043 & 0,0295 & 1,92 \\
\hline & LP/PP NODE LT.2 & NYY 4 x $4 \mathrm{~mm}^{2}$ & 5,516 & 0,303 & 0,09514 & 0,0295 & 1,45 \\
\hline & VAC LT.2 & NYY $4 \times 25 \mathrm{~mm}^{2}$ & 0,87 & 0,255 & 0,08007 & 0,0295 & 1,52 \\
\hline & VAC NODE LT.2 & NYY $4 \times 2,5 \mathrm{~mm}^{2}$ & 8,866 & 0,304 & 0,09546 & 0,0295 & 1,38 \\
\hline \multirow{4}{*}{$3^{\text {rd }}$ Floor } & LP/PP LT.3 & NYY $4 \times 6 \mathrm{~mm}^{2}$ & 3,685 & 0,288 & 0,09043 & 0,034 & 1,87 \\
\hline & LP/PP NODE LT.3 & NYY 4 x $4 \mathrm{~mm}^{2}$ & 5,516 & 0,303 & 0,09514 & 0,034 & 1,67 \\
\hline & VAC LT.3 & NYY $4 \times 25 \mathrm{~mm}^{2}$ & 0,87 & 0,255 & 0,08007 & 0,034 & 1,72 \\
\hline & VAC NODE LT.3 & $\mathrm{NYY} 4 \times 2,5 \mathrm{~mm}^{2}$ & 8,866 & 0,304 & 0,09546 & 0,034 & 1,60 \\
\hline \multirow{4}{*}{$4^{\text {th }}$ Floor } & LP/PP LT.4 & NYY $4 \times 6 \mathrm{~mm}^{2}$ & 3,685 & 0,288 & 0,09043 & 0,0385 & 3,40 \\
\hline & LP/PP NODE LT.4 & NYY 4 x $4 \mathrm{~mm}^{2}$ & 5,516 & 0,303 & 0,09514 & 0,0385 & 1,89 \\
\hline & VAC LT.4 & NYY $4 \times 16 \mathrm{~mm}^{2}$ & 1,376 & 0,255 & 0,08007 & 0,0385 & 2,15 \\
\hline & VAC NODE LT.4 & NYY $4 \times 2,5 \mathrm{~mm}^{2}$ & 8,866 & 0,304 & 0,09546 & 0,0385 & 1,81 \\
\hline
\end{tabular}

Tabel 3. Calculation of building voltage drop 


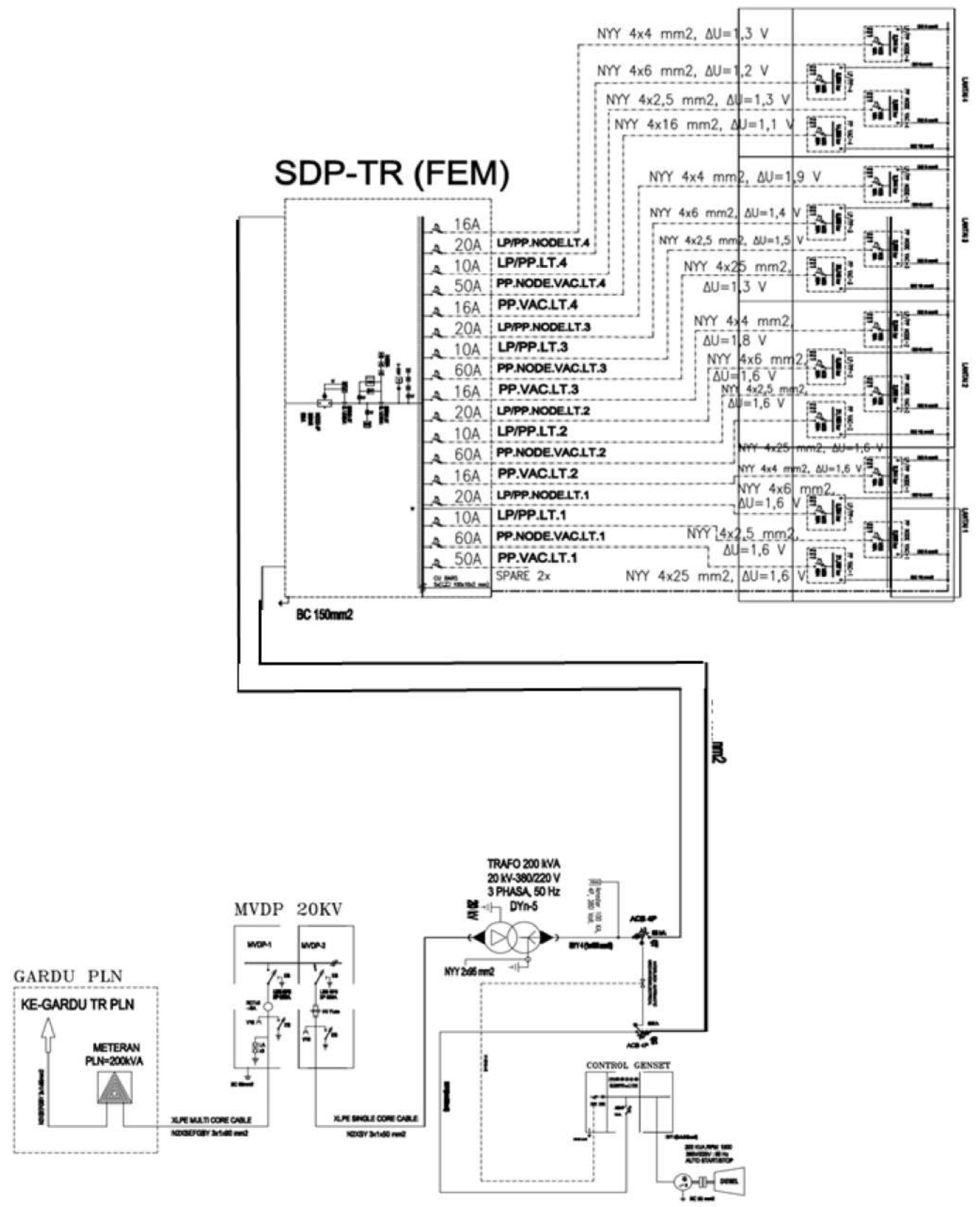

Figure 4. Electrical distribution diagram of the Faculty of Economics and Management Building 